A N N A L E S

UNIVERSITATIS MARIAE CURIE-SKŁODOWSKA LUBLIN - POLONIA

VOL. XXIX, 4

SECTIO J

2016

Dowództwo Generalne RSZ Warszawa

ANNA PISKORZ

panna.p@interia.pl

\title{
Psychologiczne czynniki bezpieczeństwa lotu próbnego pilotów wojskowych
}

Psychological Safety Factors of Test Flight Among Military Pilots

\section{STRESZCZENIE}

Celem artykułu jest analiza wyników badań dotyczących wybranych cech osobowości pilotów wykonujących loty próbne, które mogą mieć wpływ na ich bezpieczeństwo w pracy. Biorąc pod uwagę specyfikę tej profesji, wybrano trzy cechy: skłonność do ryzyka, style radzenia sobie ze stresem oraz poczucie kontroli w sytuacji pracy. Wyniki badań wskazują, że piloci oblatywacze mają zdecydowanie niską skłonność do ryzyka, czyli nie podejmują działań ryzykownych dla przyjemności czy „dreszczyku emocji”. Ich wiodącym stylem radzenia sobie w sytuacjach trudnych jest styl skoncentrowany na zadaniu, który charakteryzuje się działaniami skierowanymi na rozwiązanie problemów. Piloci wykonujący próby w locie są również osobami o wyższym niż przeciętne nasileniu poczucia kontroli wewnętrznej, zarówno w sytuacjach życiowych, jak i w sytuacji pracy. Mają zatem wyższą samoocenę, wyżej cenią swoje możliwości, z mniejszym nasileniem przeżywają problemy życiowe, są bardziej aktywni zawodowo i wierzą w możliwość sterowania własnym rozwojem.

Słowa kluczowe: ryzyko; poczucie kontroli w sytuacji pracy; style radzenia sobie ze stresem; lot próbny

\section{WPROWADZENIE}

Lot próbny statku powietrznego (oblot lub lot doświadczalny) ma na celu sprawdzenie prawidłowości działania statku powietrznego w locie (www.encyklopedia.pwn.pl). Wykonuje się go przed dopuszczeniem do eksploatacji statków 
powietrznych, m.in. po remontach i obsługach okresowych lub specjalnych. Jest to szczególna odmiana lotu, podczas którego pilot bada właściwości i zachowanie się statku powietrznego w celu wykrycia i zdiagnozowania ewentualnych nieprawidłowości w zakresie stateczności, sterowności, obciążeń i osiągów, charakterystyki przeciągnięcia i korkociągu, drgan i innych elementów przed dopuszczeniem statku powietrznego do normalnej eksploatacji.

W trakcie lotu próbnego pilot wykonuje swoje zadania za pomocą obserwacji i zamontowanej aparatury pokładowej według zatwierdzonego wcześniej programu. Podczas lotu rejestruje, nagrywa i filmuje parametry lotu badanego samolotu. Następnie na podstawie wyników lotu próbnego opracowuje sprawozdanie oraz wydaje opinię o dopuszczeniu statku powietrznego do dalszej eksploatacji (Polska Klasyfikacja Zawodów).

Pilot wykonujący loty próbne musi posiadać szeroką wiedzę z następujących dziedzin: prawo i przepisy lotnicze dotyczące klasyfikacji statków powietrznych, przepisów budowy i certyfikacji statków powietrznych oraz klasyfikacji lotów próbnych; aerodynamika i mechanika lotu; zasady konstrukcji i działania statku powietrznego, jego zespoły, układy i wyposażenie; zespoły napędowe - typowe rodzaje i układy, mierzone parametry i aparatura pomiarowa oraz rejestrująca; metodyka badania zdatności statków powietrznych na ziemi i w locie, ich interpretacja i prezentacja wyników; ocena ergonomii i czynnika ludzkiego; procedury i zasady postępowania w sytuacjach niebezpiecznych, występujących w lotach próbnych, w tym wykorzystywanie urządzeń ratowniczych statku powietrznego i osobistych członków załogi (Rozporządzenie Ministra Infrastruktury z dnia 24 czerwca 2009 r.).

W systemie bezpieczeństwa lotu próbnego decydującym czynnikiem jest człowiek. Z uwagi na odpowiedzialność za zdrowie i życie innych osób pilot wykonujący loty próbne powinien być niezawodny. $\mathrm{O}$ ile wymagania dotyczące niezawodności statków powietrznych są stosunkowo ściśle sprecyzowane, o tyle te, które dotyczą człowieka, są ciągle niesprecyzowane. Wynika z tego, że zachowania pilota są jedynie częściowo możliwe do oceny i przewidywania. Szczególnie trudne jest to w sytuacji dużego obciążenia, ryzyka i stresu.

Pilot wykonujący loty próbne powinien posiadać odpowiedni zestaw cech psychofizycznych, do których należą sprawności sensoryczne, takie jak ostrość wzroku, rozróżnianie barw, widzenie stereoskopowe, widzenie o zmroku, ostrość słuchu, zmysł równowagi czy czucie dotykowe. Powinien również posiadać odpowiednią koordynację wzrokowo-ruchową, szybki refleks, spostrzegawczość, zręczność rąk i palców, brak lęku przed wysokością. Ponadto powinien mieć zdolność koncentracji uwagi, podzielność uwagi, dobrą pamięć, wyobraźnię przestrzenną, umieć rozumować logicznie, mieć wyobraźnię i myśleć twórczo, mieć uzdolnienia rachunkowe i techniczne (Polska Klasyfikacja Zawodów). 
Wśród cech osobowościowych pilota doświadczalnego na szczególną uwagę zasługują: umiejętność pracy w szybkim tempie; łatwość przerzucania się z jednej czynności na drugą; odporność emocjonalna; samokontrola; umiejętność podejmowania szybkich i trafnych decyzji; umiejętność współdziałania; niezależność; umiejętność pracy w warunkach izolacji społecznej; samodzielność; inicjatywność; odwaga; wytrwałość; cierpliwość; dokładność; ciekawość.

Cechami przydatnymi w tym zawodzie są także: wytrzymałość na długotrwały wysiłek; umiejętność podporządkowania się; gotowość do pracy w nieprzyjemnych warunkach środowiskowych (Łuczak 2001).

$\mathrm{Na}$ podstawie literatury przedmiotu oraz doświadczeń własnych autorki do cech osobowościowych, mogących mieć wpływ na bezpieczeństwo pilota wykonującego loty próbne, zaliczono: niską skłonność do ryzyka, zadaniowy styl radzenia sobie ze stresem oraz wewnętrzne poczucie kontroli w sytuacji pracy.

Pierwszą analizowaną cechą osobowości jest skłonność do podejmowania zachowań (działań) ryzykownych. Potoczne rozumienie ryzyka sprowadza się do podejmowania działań lub decyzji w warunkach braku pewności co do osiągnięcia zamierzonego celu. $\mathrm{Z}$ kolei z matematycznego punktu widzenia ryzyko jest iloczynem prawdopodobieństwa jakiegoś wydarzenia i jego konsekwencji (Markowski 2010).

W psychologii ryzyko jest rozumiane jako wynik świadomie podjętej decyzji o potencjalnej stracie, szkodzie lub zysku, a ryzykowanie to dobrowolne zachowanie się, które może przynieść osobie ryzykującej przykrość, agresję, wypadek, stratę lub korzyść. Należy zaznaczyć, że ryzyko różni się od niebezpieczeństwa, które oznacza określone zagrożenie (Łukasiak-Goszczyńska 1997).

W literaturze przedmiotu wyróżnia się dwa rodzaje ryzyka: stymulujące, kiedy motywem jest doświadczanie przyjemności, „dreszczyk emocji”, oraz instrumentalne, którego motywem jest osiągnięcie jakiegoś ważnego celu. Podejmowanie ryzyka stymulującego jest impulsywne i charakteryzuje się niskim poziomem samokontroli oraz brakiem analizy możliwych strat. Dominuje emocjonalny system przetwarzania informacji i liczy się samo uczestnictwo w sytuacji ryzykownej (Zaleśkiewicz 2006).

Analiza sylwetki ,ryzykanta” wskazuje, że osoby te mają pewne cechy wspólne, do których należą: podzielność i zdolność do intensywnej koncentracji uwagi; skuteczne reagowanie na wiele współwystępujących bodźców; zapamiętywanie złożonego materiału; oryginalność; innowacyjność. Osoby poszukujące ryzykownych działań potrafią sprawnie funkcjonować w sytuacji wysokiego obciążenia stymulacyjnego i nie jest ono źródłem lęku czy niepokoju (Łukasiak-Goszczyńska 1997).

Drugi rodzaj ryzyka pozbawiony jest emocji i przyjemności, ponieważ ryzyko instrumentalne jest traktowane jako narzędzie - instrument do osiągnięcia zamierzonego celu. Ten rodzaj ryzyka jest kontrolowany, nie ma w nim dzia- 
łań spontanicznych, a podejmowana ryzykowna aktywność jest efektem zimnej kalkulacji z nastawieniem na uzyskanie założonego wyniku. Występuje tu wysoki poziom samokontroli osoby ryzykującej, która koncentruje się na szacowaniu wielkości ewentualnych strat. Ryzykowanie instrumentalne motywuje do odpowiedniego zachowania się (strategii, taktyki) w drodze do osiągnięcia założonego celu. Zakłada się, że podjęcie tego typu ryzyka wynika z różnie rozumianej konieczności, czyli jest powodowane przymusem podjęcia takiej aktywności (Zaleśkiewicz 2006).

W działalności lotniczej ryzyko instrumentalne istnieje zawsze, lecz akceptować można tylko pewien poziom ryzyka. Jeśli ryzyko wykonania zadania jest znaczne, należy je zmniejszyć do poziomu akceptowalnego lub odstąpić od wykonania zadania (Markowski, Smolicz 2012).

Nie można natomiast ani akceptować, ani tolerować w lotnictwie ryzyka stymulującego. Zawód pilota wojskowego jest profesją szczególną, ponieważ jest związany z: wysokimi predyspozycjami fizycznymi i psychicznymi; kosztowną nauką połączoną z opanowaniem sztuki pilotażu; pracą w warunkach niespotykanych w innych zawodach; ogromną odpowiedzialnością za wartościowy sprzęt i charakter wykonywanych zadań. Dlatego w tej grupie zawodowej nie mogą funkcjonować osoby, które podejmują działania ryzykowne dla doznania przyjemności.

Cechą osobowości, która może mieć wpływ na bezpieczne wykonywanie zadań przez pilota doświadczalnego (oblatywacza), jest styl radzenia sobie ze stresem.

Stres oznacza nieswoistą (specyficzną) reakcję organizmu, która jest wywoływana przez różnorodne bodźce (tzw. stresory). Stresorami mogą być: czynniki fizyczne (zimno, ciepło); czynniki biofizyczne (infekcje, zatrucia organizmu); bodźce o charakterze psychologicznym (napięcie emocjonalne), które mogą wywoływać szereg chorób somatycznych. Taki skutek stresu jest wynikiem niezdolności człowieka do radzenia sobie z nim (Reykowski 1996).

We współczesnej literaturze przedmiotu rozróżnia się biologiczne i psychologiczne podejście do stresu. Teoria stresu biologicznego ogranicza się tylko do analizy zmian fizjologicznych zachodzących w organizmie pod wpływem czynników zewnętrznych. Zatem stres ujmowany jest w kategoriach reakcji. Teoria ta jest ciągle powszechnie akceptowana, przede wszystkim ze względu na preferowane w medycynie konkretne i jednoznaczne rozstrzygnięcia (Heszen-Niejodek 2000).

Natomiast psychologiczne podejście traktuje stres jako stan, w którym jednostka doświadcza silnych emocji negatywnych, takich jak np. strach, lęk, złość czy wrogość. Emocjom tym towarzyszą zmiany fizjologiczne i biochemiczne, wyraźnie przekraczające spoczynkowy poziom aktywacji (inaczej pobudzenia). Stan stresu spowodowany jest brakiem równowagi między wymaganiami a możliwościami jednostki co do radzenia sobie z nim (Strelau 1996). 
Stres jest nieodłącznym elementem współczesnego życia, a przede wszystkim funkcjonowania w sytuacji pracy. Jednak nie zawsze jest on przykrą reakcją na sytuacje negatywne. Oprócz przykrych przypadków stres pojawia się również podczas stanów emocjonalnych towarzyszących miłym wydarzeniom życiowym, np. podczas otrzymania awansu, podwyżki, wyróżnienia - czasami wręcz uskrzydla, dodaje sił, wzmaga motywację. Stąd też wynika kolejny podział stresu na pozytywny (mobilizujący) i negatywny (destrukcyjny) (Heszen-Niejodek 2000).

Pierwszy z nich mobilizuje, pobudza organizm, wyzwala energię i pozwala skuteczniej pokonywać przeszkody. Jest siłą napędową do podejmowania wyzwań i szybszego rozwiązywania trudnych zadań. Inne zalety pozytywnego stresu to wzmacnianie koncentracji, refleksu, wyostrzenie uwagi i zwiększenie wydajności mózgu. Jednak kiedy zapotrzebowanie na adrenalinę nie maleje ani przez chwilę, mimo że trwamy w euforii, dobry stres przekształca się w stres negatywny, który może wywoływać apatię, problemy ze snem, płaczliwość, niecierpliwość, nagłe kołatanie serca, bóle głowy, przesadne reakcje emocjonalne, gniew czy depresję.

W sensie fizjologicznym nie ma różnicy między stresem dobrym i złym. W obu przypadkach jest podobne pobudzenie (aktywacja) organizmu do walki z nim. W sensie psychologicznym pojawiają się jednak wyraźne różnice - stres zły (dystres) rozumiany jest jako niosący cierpienie i dezintegrację, natomiast stres dobry (eustres) jest czynnikiem motywującym do wysiłku pomimo trudności, prowadzącym do rozwoju własnej osobowości i osiągnięć życiowych. Wszystko zależy od oceny poznawczej, od tego, jaki sens nadajemy stresowi (Strelau 1996).

W ostatnich dziesięcioleciach coraz częściej przedmiotem badań staje się nie tyle doświadczanie stresu, ile podejmowana przez człowieka aktywność mająca na celu poradzenie sobie ze stresującymi wydarzeniami, określana pojęciem radzenia sobie ze stresem. O skutkach stresu decyduje bowiem w większym stopniu radzenie sobie niż obiektywne właściwości stresora.

Styl radzenia sobie to dyspozycja do radzenia sobie w określony sposób. To behawioralna i poznawcza odpowiedź na niewygodną czy trudną sytuację. Różnica między stylem a strategiami radzenia sobie polega na tym, że styl to trwała dyspozycja człowieka do określonego zmagania się z sytuacjami stresowymi, a strategie radzenia sobie to określone sposoby działania, jakie jednostka podejmuje w konkretnej sytuacji stresowej (Szczepaniak, Strelau, Wrześniewski 1996).

Radzenie sobie jest świadomą odpowiedzią na zewnętrzne stresujące wydarzenia. Każdy człowiek ma swój charakterystyczny wzór reagowania na różnego rodzaju wydarzenia - styl, na który składają się różne strategie radzenia sobie. Wyróżnia się trzy style radzenia sobie w sytuacjach trudnych: zadaniowy, emocjonalny i unikowy.

Inną cechą osobowości, która może mieć wpływ na bezpieczeństwo pilota w locie próbnym, jest poczucie kontroli w sytuacji pracy. Skłonność do przypisy- 
wania sobie bądź czynnikom zewnętrznym wpływu na bieg zdarzeń i wyniki własnych działań związana jest z lokalizacją kontroli i w psychologii jest określana jako umiejscowienie poczucia kontroli.

Zgodnie z teorią społecznego uczenia się człowiek może zaspokoić swoje potrzeby dzięki różnym zachowaniom instrumentalnym. Uzyskiwane w ten sposób wzmocnienia zwiększają oczekiwanie, że w przyszłości po takim zachowaniu znowu nastąpią wzmocnienia. Pojawia się zatem przeświadczenie o skuteczności własnego działania. Sposób, w jaki spostrzegane są związki przyczynowe między zachowaniem a wzmocnieniami, traktowany jest jako kontinuum. Jeśli człowiek przekonuje się, że osiąganie wzmocnienia zależy od jego własnego postępowania, zaczyna przypisywać sobie kontrolę nad wzmocnieniami. Takie przeświadczenie jest nazywane poczuciem kontroli wewnętrznej. W przypadku doświadczeń negatywnych (tzn. spostrzegania zależności wzmocnień od świata zewnętrznego przypadku, szczęścia, przeznaczenia, działania innych ludzi) człowiek utwierdza się w poczuciu kontroli zewnętrznej (Gliszczyńska 1990).

Mimo że poczucie kontroli wewnętrznej lub zewnętrznej ma charakter nabyty - zależy od życiowych doświadczeń człowieka - to jest na tyle trwałe, że różnicuje oczekiwania poszczególnych ludzi i ich postępowanie.

W ciągu ostatnich kilkudziesięciu lat przeprowadzono wiele badań w różnych grupach wiekowych, z których wynika jednoznacznie, że ludzie z poczuciem kontroli wewnętrznej funkcjonują inaczej niż ludzie z poczuciem kontroli zewnętrznej. Okazało się, że istnieje dodatnia zależność między wewnętrznym poczuciem kontroli a większym zaangażowaniem ludzi w sytuacji zadaniowej. Badania ujawniły również, że osoby z poczuciem kontroli wewnętrznej w porównaniu z osobami z poczuciem kontroli zewnętrznej charakteryzują się wyższą samooceną i mniejszym nasileniem przeżywanych problemów życiowych, co prawdopodobnie korzystnie wpływa na dobre samopoczucie i poziom zadowolenia (Siekańska 2005).

Osoby z wewnętrznym poczuciem kontroli mają również wyższą samoocenę, wyżej oceniają swoje możliwości oraz wierzą w możliwość sterowania własnym rozwojem. Z kolei przekonanie o niemożności własnego wpływu na bieg wypadków przejawia się zniechęceniem do jakiejkolwiek aktywności w danej sprawie. Skrajne zewnętrzne poczucie kontroli wiąże się z apatią, biernością, lękiem przed samodzielnością (Siekańska 2005).

Uważa się, że poczucie kontroli jest względnie trwałą cechą osobowości o dużym znaczeniu dla funkcjonowania człowieka, szczególnie w sytuacji zagrożenia czy stresu w pracy. Na podstawie przeprowadzonych badań stwierdzono, że poczucie kontroli (jako cecha osobowości) koreluje z sytuacyjnym poczuciem możliwości kontrolowania zagrożeń na stanowisku pracy. Zależność taka występowała w sytuacjach bezpośredniego zagrożenia pracownika. Oceniając wysoko 
kontrolowalność zdarzeń, osoby z wewnętrznym poczuciem kontroli mogą akceptować wyższe ryzyko niż osoby z zewnętrznym poczuciem kontroli. Wyniki dowiodły, że zarówno cechy temperamentalne (aktywacja i wrażliwość), jak i poziom lęku, a przede wszystkim poczucie kontroli, odgrywają znaczącą rolę $\mathrm{w}$ procesie percepcji i oceny ryzyka. Wyjaśniają one w dużym stopniu zmienność dokonywanych przez ludzi ocen, wyborów i zachowań w sytuacji zagrożenia (Łukasiak-Goszczyńska 1997)

\section{WYNIKI BADAŃ}

Celem badań było określenie poziomu natężenia wybranych cech osobowościowych mających wpływ na bezpieczeństwo pilotów wykonujących loty próbne oraz porównanie natężenia tych cech z grupą pilotów, którzy nie wykonują lotów doświadczalnych.

Problemy badawcze sformułowano w postaci pytań dopełnienia: jaka jest skłonność do ryzyka, jaki jest styl radzenia sobie ze stresem i jakie jest poczucie kontroli pilotów oblatywaczy i pilotów niewykonujących lotów próbnych oraz jakie są różnice i podobieństwa między obiema grupami w natężeniu wybranych cech osobowościowych mających wpływ na bezpieczeństwo lotów próbnych.

Badania przeprowadzono w grupie losowo wybranych 66 pilotów wykonujących loty próbne oraz 70 pilotów niewykonujących takich zadań. Wszyscy badani piloci ukończyli 40. rok życia, posiadali staż zawodowej służby wojskowej powyżej 15 lat oraz byli żonaci. Ponadto większość pilotów wykonujących loty próbne posiadała klasę mistrzowską i nalot życiowy powyżej 2000 godzin, natomiast pozostali piloci legitymowali się w większości klasą pierwszą i nalotem życiowym w przedziale 1500-2000 godzin. Zdecydowana większość badanych pilotów wykonywała loty na samolotach transportowych.

Do szczegółowej charakterystyki skłonności do ryzyka, stylów radzenia sobie w sytuacjach trudnych oraz poczucia kontroli w sytuacji pracy wykorzystano statystyki opisowe z uwzględnieniem następujących danych: średnia, mediana, odchylenie standardowe, które są miarami tendencji centralnej oraz minimum i maksimum. Średnia stanowi centrum, środek ciężkości zbioru pomiarów, mediana zaś jest wartością dzielącą wszystkie pomiary na pół, czyli tak, że połowa pomiarów mieści się poniżej niej, a połowa - powyżej.

$\mathrm{W}$ celu poszukiwania podobieństw i różnic $\mathrm{w}$ natężeniu wybranych cech osobowościowych między pilotami oblatywaczami a pilotami niewykonującymi prób w locie zastosowano test istotności różnic t-Studenta dla grup niezależnych. Dla tego testu parametrycznego przyjęto następujące założenia: jeżeli $t<t(\alpha, v)$, to brak zróżnicowania (natężenie badanych cech jest podobne), natomiast jeżeli $\mathrm{t} \geq \mathrm{t}(\alpha, v)$, to zróżnicowanie jest istotne statystycznie (nieprzypadkowe). W przedstawionych założeniach t oznacza wartość empiryczną, $\mathrm{t}(\alpha, v)$ - wartość teoretycz- 
ną (krytyczną), natomiast $\alpha$ - poziom istotności p, który w wielu dziedzinach badań, szczególnie badań społecznych, przyjmuje $p(\alpha) \leq 0,05$. Poniżej tej wartości rezultat oceniany jest jako statystycznie istotny. $Z$ kolei $v$ oznacza stopnie swobody (df), 65 - czyli liczbę wartości, które mają swobodę zmieniania się.

Do badania pilotów wykorzystano: Test Zachowań Ryzykownych (TZR) autorstwa S. Studenckiego, służący do pomiaru skłonności do podejmowania zachowań ryzykownych; Kwestionariusz Radzenia Sobie w Sytuacjach Stresowych (CISS) - adaptacja polska J. Strelau, A. Jaworowska, K. Wrześniewski, P. Szczepaniak, określający style radzenia sobie z problemami; Skalę I-E w Pracy opracowaną przez X. Gliszczyńską, przeznaczoną do badania poczucia kontroli w sytuacji pracy.

\section{SKŁONNOŚĆ DO RYZYKA}

Niski poziom skłonności do ryzyka jest jedną z cech osobowościowych, które mogą mieć wpływ na bezpieczeństwo pilota wykonującego loty próbne. Poziom tej cechy oceniono za pomocą Testu Zachowań Ryzykownych R. Studenckiego, który diagnozuje osoby preferujące zachowania związane z ryzykiem w zróżnicowanym wymiarze bądź osoby, które starają się unikać zachowań ryzykownych, preferując opcje związane z bezpieczeństwem, pewnością, spokojem.

Test jest oparty na założeniu, iż ludzie charakteryzujący się wysokim poziomem skłonności do ryzyka odczuwają w większym stopniu od jednostek o niskiej skłonności do ryzyka potrzebę podjęcia zachowań ryzykownych oraz częściej od nich faktycznie tego rodzaju zachowania podejmują (Studencki [red.] 2004).

Przyjęto, że czynnikiem różnicującym osoby odznaczające się skłonnością do ryzyka od osób stroniących od ryzykowania jest częstość uczestnictwa w sytuacjach o podwyższonym ryzyku oraz większa częstość doznawania satysfakcji w powiązaniu z zachowaniem ryzykownym lub w następstwie takiego zachowania.

Test Zachowań Ryzykownych składa się z 25 twierdzeń dotyczących stosunku badanego do trudnych lub niebezpiecznych zadań. Zadaniem osób badanych było określenie, przy użyciu pięciostopniowej skali, jak często podejmowali wymienione zachowanie. Skala jest opisana w taki sposób, że zaznaczenie 4 oznacza, że dane zachowanie jest podejmowane bardzo często, natomiast 0 sygnalizuje, że badany bardzo rzadko lub nigdy nie podejmuje wymienionego zachowania. Wysokie wyniki uzyskane w Teście Zachowań Ryzykownych wskazują na częste angażowanie się danej osoby w zachowania ryzykowne (Porczyńska 2006). Wyniki tego testu mieszczą się w przedziale od minimum 0 pkt do maksymalnie 100 pkt. 
Tab. 1. Zachowania ryzykowne pilotów

\begin{tabular}{|l|c|c|}
\hline \multicolumn{1}{|c|}{ Dane } & $\begin{array}{c}\text { Piloci wykonujący } \\
\text { loty próbne }\end{array}$ & $\begin{array}{c}\text { Piloci - grupa } \\
\text { porównawcza }\end{array}$ \\
\hline Liczebność & 66 & 70 \\
\hline Średnia arytmetyczna & 20,39 & 20,66 \\
\hline Odchylenie standardowe & 6,64 & 5,23 \\
\hline Test t-Studenta & \multicolumn{2}{|c|}{0,181} \\
\hline Poziom istotności & \multicolumn{2}{|c|}{0,857} \\
\hline
\end{tabular}

Źródło: opracowanie własne.

Z badań empirycznych wynika, że piloci wojskowi mają zdecydowanie niską skłonność do ryzyka - wynik dla pilotów wykonujących loty próbne wynosi średnio 20,39, odchylenie standardowe 6,64, mediana 19,00, minimum 17, maksimum 33. Średnia wartość skłonności do ryzyka pilotów z grupy porównawczej wynosi 20,66 i jest nieznacznie wyższa od średniej pilotów doświadczalnych, odchylenie standardowe 5,23, mediana 19,00, minimum 15, maksimum 29 (tab. 1).

Za pomocą testu statystycznego t-Studenta dla grup niezależnych dokonano porównania średnich poziomów skłonności do ryzyka. Na podstawie uzyskanego wyniku $\mathrm{t}=|0,181|$ należy stwierdzić, że nie ma istotnych statystycznie różnic między skłonnością do ryzyka pilotów wykonujących loty próbne i pilotów z grupy porównawczej.

Można zatem przypuszczać, że piloci wojskowi w codziennym życiu i w pracy zawodowej nigdy: nie wybierają drogi na niebezpieczne skróty; nie prowokują niebezpiecznych zdarzeń, by przeżyć dreszczyk emocji; nie odstępują od przepisów bezpieczeństwa, by zrobić coś szybciej, taniej lub mniejszym wysiłkiem; nie ryzykują, aby pokazać innym, że mają ,fart”; nie podejmują ryzyka, by poprawić swoje samopoczucie; nie wybierają ryzykownych rozwiązań, aby odczuć przyjemność. Rzadko biorą udział w trudnych i niebezpiecznych przedsięwzięciach, w których ich życie lub zdrowie może być zagrożone, rzadko też stawiają sobie cele wymagające podjęcia ryzyka, czasami - mimo że wiedzą, co im szkodzi - nie unikają tego, niezbyt często wybierają ryzykowne rozwiązania niż ostrożne oraz zdarza im się nie mieć pewności, czy ich postępowanie zakończy się sukcesem czy porażką.

\section{STYLE RADZENIA SOBIE ZE STRESEM}

Do oceny stylu radzenia sobie ze stresem pilotów wykorzystano Kwestionariusz Radzenia Sobie w Sytuacjach Stresowych (CISS) - adaptacja polska J. Strelau, A. Jaworowska, K. Wrześniewski, P. Szczepaniak - który bada style radzenia 
sobie z problemami. Kwestionariusz składa się z 48 stwierdzeń dotyczących różnych zachowań, jakie ludzie podejmują w sytuacjach stresowych. Obok każdego stwierdzenia umieszczone były cyfry od 1 do 5, określające częstotliwość, z jaką dana aktywność jest podejmowana w sytuacjach trudnych, stresowych. Kwestionariusz CISS określa trzy skale składające się z 16 pozycji każda. Osoby badane uzyskały w każdej z nich od 16 do 80 pkt. Skale te określają trzy style radzenia sobie ze stresem: styl skoncentrowany na zadaniu (SSZ), styl skoncentrowany na emocjach (SSE), styl skoncentrowany na unikaniu (SSU) (Strelau i in. 2005).

Tab. 2. Style radzenia sobie w sytuacjach trudnych

\begin{tabular}{|l|c|c|c|c|c|c|}
\hline \multirow{2}{*}{\multicolumn{1}{|c}{ Style radzenia sobie }} & \multicolumn{2}{|c|}{$\begin{array}{c}\text { Piloci wykonujący } \\
\text { loty próbne }\end{array}$} & $\begin{array}{c}\text { Piloci - grupa po- } \\
\text { równawcza }\end{array}$ & \multicolumn{2}{c|}{ Test t-Studenta } \\
\cline { 2 - 8 } & $\mathrm{M}$ & $\mathrm{SD}$ & $\mathrm{M}$ & $\mathrm{SD}$ & $\mathrm{t}^{\circ}$ & $\mathrm{p}$ \\
\hline Styl skoncentrowany na zadaniu & 60,97 & 5,95 & 59,23 & 5,06 & $-1,303$ & 0,197 \\
\hline Styl skoncentrowany na emocjach & 28,58 & 9,74 & 37,60 & 2,60 & 5,285 & 0,000 \\
\hline Styl skoncentrowany na unikaniu & 37,00 & 6,86 & 43,49 & 4,85 & 4,519 & 0,000 \\
\hline
\end{tabular}

Źródło: opracowanie własne.

Styl skoncentrowany na zadaniu określa styl radzenia sobie ze stresem polegający na podejmowaniu zadań. Osoby uzyskujące wysokie wyniki w tej skali mają w sytuacjach stresowych tendencję do podejmowania wysiłków zmierzających do rozwiązania problemu przez poznawcze przekształcenia lub próby zmiany sytuacji. Główny nacisk położony jest na zadanie lub planowanie rozwiązania problemu (Strelau i in. 2005).

Na podstawie danych empirycznych stwierdzono, że piloci wojskowi uzyskali wysokie wyniki w tej skali. Dla pilotów doświadczalnych średnia wynosi 60,97, odchylenie standardowe 5,95, mediana 59,00, minimum 55, maksimum 68 . Natomiast dla pilotów z grupy porównawczej średnia wartość stylu skoncentrowanego na zadaniu wynosi 59,23 i jest nieznacznie niższa od średniej pilotów doświadczalnych, odchylenie standardowe 5,06, mediana 60,00, minimum 51, maksimum 63 (tab. 2).

Można zatem założyć, że zadaniowy styl radzenia sobie w sytuacjach trudnych jest wiodącym sposobem radzenia sobie ze stresem. W codziennym funkcjonowaniu osobistym i zawodowym zarówno piloci wykonujący loty próbne, jak i piloci z grupy porównawczej częściej koncentrują się na problemach, zastanawiając się, jak je rozwiązać. Ponadto analizują je, lepiej planują swój czas, zwykle ustalają, co w danej sytuacji jest najważniejsze, zawsze starają się zrozumieć sytuację, uczą się na własnych błędach, dążą do kontrolowania sytuacji oraz częściej podejmują dodatkowy wysiłek, aby załatwić sprawę. 
Styl skoncentrowany na emocjach dotyczy stylu charakterystycznego dla osób, które w sytuacjach stresowych wykazują tendencję do koncentracji na sobie, na własnych przeżyciach emocjonalnych, takich jak złość, poczucie winy, napięcie. Osoby te mają także tendencję do myślenia życzeniowego i fantazjowania. Działania takie mają na celu zmniejszenie napięcia emocjonalnego związanego z sytuacją stresową. Czasami jednak mogą powiększać poczucie stresu i powodować wzrost napięcia lub przygnębienie (Strelau i in. 2005).

W skali SSE wyniki badań są zróżnicowane na poziomie istotnym statystycznie $t=|5,285|$ przy $\mathrm{p}=0,000$. Piloci wykonujący loty próbne uzyskali średnią 28,58 , odchylenie standardowe 9,94, medianę 34,00, minimum 17, maksimum 40. Natomiast $\mathrm{w}$ grupie porównawczej średnia wynosi 37,60 , odchylenie standardowe 2,60, mediana 38,00 , minimum 37 , maksimum 40 . Oznacza to, że piloci z grupy porównawczej częściej niż piloci doświadczalni reagują emocjonalnie w sytuacji stresu. W trudnych dla siebie momentach stają się bardzo napięci; nie zawsze wiedzą, co mają zrobić; częściej wpadają w złość, wyładowując się na innych; skupiają się na swoich dolegliwościach fizycznych; obwiniają siebie za to, że nie wiedzą, co mają zrobić; skupiają się na swoich brakach.

Styl skoncentrowany na unikaniu określa styl radzenia sobie ze stresem charakterystyczny dla osób, które w sytuacjach stresowych wykazują tendencję do wystrzegania się myślenia, przeżywania i doświadczania tej sytuacji. Styl skoncentrowany na unikaniu może przyjmować dwie formy: angażowanie się w czynności zastępcze (np. oglądanie telewizji, objadanie się, myślenie o sprawach przyjemnych, sen, ,robienie sobie wolnego", by uciec od problemu) albo poszukiwanie kontaktów towarzyskich (Strelau i in. 2005).

$\mathrm{Z}$ danych empirycznych wynika, że piloci wojskowi charakteryzują się przeciętnymi wynikami w skali SSU - piloci oblatywacze uzyskali średnią 37,00, odchylenie standardowe 6,86, medianę 34,00, minimum 33, maksimum 50. Średnia wartość stylu skoncentrowanego na unikaniu w grupie porównawczej wynosi 43,49 , odchylenie standardowe 4,85, mediana 44,00, minimum 35, maksimum 48 . Wartość testu t-Studenta $t=|4,519|$ przy $\mathrm{p}=0,000$ wskazuje na istotne statystycznie różnice między pilotami wykonującymi loty próbne a pilotami z grupy porównawczej w stosowaniu stylu skoncentrowanego na unikaniu - badani z grupy porównawczej w sytuacji stresowej wykorzystują go częściej.

Styl radzenia sobie ze stresem jest względnie stałą, specyficzną dla człowieka tendencją, wyznaczającą przebieg działania podejmowanego w odpowiedzi na powstały stres. Stanowi charakterystyczny dla jednostki zestaw strategii radzenia sobie w sytuacjach stresowych. W procesie tym uczestniczy tylko część spośród strategii pozostających w repertuarze jednostki, należących do danego stylu (Reykowski 1996).

Nie można jednoznacznie stwierdzić, który z powyższych stylów jest dla jednostki najbardziej korzystny. Okazuje się bowiem, że dla efektywności podejmo- 
wanych działań najważniejszą rolę odgrywa elastyczność w wyborze strategii, która oznacza łatwość dostosowania sposobu działania do wymagań konkretnej sytuacji, konkretnego wydarzenia. Posiadanie dużego repertuaru sposobów zwalczania stresu zwiększa zatem prawdopodobieństwo ich dopasowania do aktualnej sytuacji.

Na podstawie uzyskanych wyników badań można stwierdzić, że piloci wojskowi najczęściej wykorzystują w sytuacjach trudnych styl zadaniowy, a dopiero w dalszej kolejności unikowy i emocjonalny. Zauważono jednak wyraźne różnice między badanymi grupami w częstotliwości stosowania tych strategii, ponieważ piloci wykonujący loty próbne w odpowiedzi na stres zdecydowanie częściej reagują zadaniowo, a zdecydowanie rzadziej - emocjonalnie i unikowo.

\section{POCZUCIE KONTROLI W SYTUACJI PRACY}

Do zbadania lokalizacji poczucia kontroli w grupie pilotów wojskowych posłużyła Skala I-E w Pracy X. Gliszczyńskiej. Narzędzie przeznaczone jest do pomiaru dwóch aspektów poczucia kontroli - zgeneralizowanego i sytuacyjnego. Skala złożona jest z następujących podskal: Sytuacja Pracy (SP) oraz Filozofia Życiowa (FŻ). W wyniku badania otrzymaliśmy trzy wyniki: ogólny, w podskali SP oraz w podskali FŻ. Wynik ogólny mieści się w granicach od 0 do 25 pkt. Wynik SP może przyjmować wartości w przedziale od 0 do 13 pkt, natomiast dla podskali FŻ jest to przedział od 0 do 12 pkt. Średnia wyborów świadczy o poczuciu kontroli wewnętrznej. Im większą przyjmuje wartość, tym większe jest nasilenie tej cechy osobowości (Gliszczyńska 1990).

Tab. 3. Poczucie kontroli w sytuacji pracy

\begin{tabular}{|l|c|c|c|c|c|c|}
\hline \multirow{2}{*}{ Aspekty poczucia kontroli } & \multicolumn{2}{|c|}{$\begin{array}{c}\text { Piloci wykonujący } \\
\text { loty próbne }\end{array}$} & \multicolumn{2}{c|}{$\begin{array}{c}\text { Piloci - grupa po- } \\
\text { równawcza }\end{array}$} & \multicolumn{2}{c|}{ Test t-Studenta } \\
\cline { 2 - 8 } & $\mathrm{M}$ & $\mathrm{SD}$ & $\mathrm{M}$ & $\mathrm{SD}$ & $\mathrm{t}^{\circ}$ & $\mathrm{p}$ \\
\hline Wynik ogólny poczucia kontroli & 20,18 & 1,68 & 19,97 & 3,46 & $-0,316$ & 0,753 \\
\hline Podskala Filozofia Życiowa & 9,15 & 1,89 & 9,69 & 1,76 & 1,206 & 0,232 \\
\hline Podskala Sytuacja Pracy & 11,03 & 0,88 & 10,29 & 1,99 & $-2,010$ & 0,050 \\
\hline
\end{tabular}

Źródło: opracowanie własne.

Z analizy badań empirycznych wynika (tab. 3), że w odniesieniu do grupy normalizacyjnej (średnia wartość 14,33) piloci wojskowi prezentują zdecydowanie wyższy ogólny poziom poczucia kontroli w sytuacji pracy - piloci wykonujący loty próbne uzyskali średnią 20,18 , odchylenie standardowe 1,68 , medianę 21,00, minimum 17, maksimum 22. W grupie porównawczej średnia wartość 
wynosi 19,97 , odchylenie standardowe 3,46 , mediana 22,00 , minimum 13 , maksimum 24. Zaprezentowane dane dowodzą również, że między średnimi wynikami obu grup nie ma istotnej statystycznie różnicy w nasileniu tej cechy osobowości - test t-Studenta wynosi $\mathrm{t}=|0,316|$.

Wyniki pilotów wojskowych uzyskane w podskali Filozofia Życiowa również mieszczą się powyżej średniej grupy normalizacyjnej (średnia wartość 6,48) - piloci wykonujący loty próbne uzyskali średnią 9,15, odchylenie standardowe 1,89 , medianę 9,00 , minimum 6 , maksimum 11 , a w grupie porównawczej średnia wynosi 9,69 , odchylenie standardowe 1,76 , mediana 10,00 , minimum 6 , maksimum 11. Na podstawie wartości testu $t-S t u d e n t a t=|1,206|$ można stwierdzić, że nie ma istotnej statystycznie różnicy między natężeniem tej zmiennej w obu grupach.

Wysokie poczucie kontroli wewnętrznej w różnych sytuacjach życiowych wyrażane jest różnymi opiniami. Większość pilotów wojskowych uważa, że mają wpływ na własne życie. Tylko od nich zależy, czy potrafią złe przypadki obrócić na swoją korzyść i uznać, że niepowodzenia, jakie ich spotykają, są najczęściej wynikiem błędów popełnianych przez nich samych.

Duża grupa badanych jest zdania, że ludzie, których nazywa się szczęściarzami, potrafią po prostu ocenić realistycznie wymagania sytuacji i swoje możliwości. Najczęściej sami są odpowiedzialni za to, co im się przytrafia. Nie zdają się na los, w życiu bowiem lepiej wychodzi się na decydowaniu o własnych sprawach, a walkę z losem uważają za naturalną konieczność.

W opinii większości badanych każdy człowiek w miarę doświadczenia życiowego ogranicza swoją zależność od innych. Szacunek, jakim cieszą się ludzie, jest najczęściej wynikiem ich zasług. Jednak zbyt często wiele osób jest niedocenionych nawet wtedy, gdy w pełni na to zasługują.

W podskali Sytuacja Pracy wyniki badań są zróżnicowane na poziomie istotnym statystycznie $\mathrm{t}=|2,010|$ przy $\mathrm{p}=0,050$. Średnia wartość $\mathrm{w}$ tej podskali $\mathrm{w}$ grupie pilotów oblatywaczy wynosi 11,03 , odchylenie standardowe 0,88 , mediana 11,00 , minimum 10 , maksimum 12 . Piloci z grupy porównawczej uzyskali średnią 10,29, odchylenie standardowe 1,99 , medianę 10,00 , minimum 6 , maksimum 13. Uzyskane wyniki w obu grupach są zdecydowanie wyższe od wyników grupy normalizacyjnej (średnia 7,84) i świadczą o wysokim natężeniu wewnętrznego poczucia kontroli w sytuacji pracy.

Poczucie kontroli w sferze aktywności zawodowej jest najwyższe u pilotów wykonujących loty próbne. Uważają oni, że w większości przypadków można sobie poradzić z trudnościami, jakie napotykają w pracy oraz że dobre przygotowanie zawodowe jest gwarancją otrzymania odpowiedniej pracy. Są też przekonani, że prędzej czy później pracownik zdobywa taką opinię, na jaką sobie zasłużył.

Większość pilotów przyznało, że przez umiejętne postępowanie można wpływać nawet na własnych przełożonych. Większość badanych osób zgadza się rów- 
nież z opinią, że wśród ludzi pełniących podobne funkcje jedni są dużo bardziej samodzielni od innych, co zależy od ich charakteru, a jeśli pracownik posiada autorytet zawodowy, to przełożeni częściej liczą się z jego opiniami.

Część badanych osób uważa, że już sama pozycja przełożonego daje mu możliwość kierowania podwładnymi, dlatego piloci wojskowi w większości wolą wziąć na siebie jakieś ryzyko po to, by uniknąć wtrącania się przełożonego do codziennej pracy.

\section{ZAKOŃCZENIE}

Podsumowując wyniki badań, można stwierdzić, że piloci wojskowi są w zdecydowanej większości osobami o wyższym niż przeciętne nasileniu poczucia kontroli wewnętrznej zarówno w skali ogólnej, jak i w podskalach Filozofia Życiowa i Sytuacja Pracy.

Prezentowane badania empiryczne dotyczyły wybranych cech osobowości, które mogą mieć wpływ na bezpieczeństwo pilota wykonującego loty próbne. Biorąc pod uwagę specyfikę tej profesji, wybrano trzy cechy: skłonność do ryzyka, style radzenia sobie ze stresem oraz wewnętrzne poczucie kontroli w sytuacji pracy.

Wyniki badań wskazują, że piloci wojskowi wykonujący loty próbne mają zdecydowanie niską skłonność do ryzyka, czyli nie podejmują działań ryzykownych dla przyjemności czy „dreszczyku emocji”. Ich wiodącym stylem radzenia sobie w sytuacjach trudnych jest styl skoncentrowany na zadaniu, który charakteryzuje się działaniami skierowanymi na rozwiązywanie problemów.

Piloci wykonujący próby w locie są osobami o wyższym niż przeciętne nasileniu poczucia kontroli wewnętrznej zarówno w sytuacjach życiowych, jak i w sytuacji pracy. Mają zatem wyższą samoocenę, wyżej cenią swoje możliwości, z mniejszym nasileniem przeżywają problemy życiowe. Są bardziej aktywni zawodowo, wierzą w możliwość sterowania własnym rozwojem, interpretują sytuacje w kategoriach sprawnościowych i perspektywicznych - „to da się zrobić”, co pobudza do twórczego poszukiwania rozwiązań ,jak to zrobić” (Siekańska 2005). W sytuacji bezpośredniego zagrożenia czy stresu mogą akceptować wyższe ryzyko (Łukasiak-Goszczyńska 1997).

\section{BIBLIOGRAFIA}

Gliszczyńska X. (1990), Skala I-E w Pracy. Technika pomiaru poczucia kontroli w sytuacji pracy, Warszawa: Pracownia Testów Psychologicznych.

Heszen-Niejodek I. (2000), Teoria stresu psychologicznego i radzenia sobie, [w:] J. Strelau (red.), Psychologia. Podręcznik akademicki. Jednostka w społeczeństwie i elementy psychologii stosowanej, t. 3, Gdańsk: Gdańskie Wydawnictwo Psychologiczne. 
Łuczak A. (2001), Wymagania psychologiczne w doborze osób do zawodów trudnych, Warszawa: Centralny Instytut Ochrony Pracy.

Łukasiak-Goszczyńska M. (1997), Człowiek wobec zagrożeń. Psychospołeczne uwarunkowania oceny i akceptacji ryzyka, Warszawa: Wydawnictwo Akademickie „Żak”.

Markowski R. (2010), Ryzyko i stres w lotnictwie sportowym, Warszawa: Difin.

Markowski R., Smolicz T. (2012), Czynnik ludzki w operacjach lotniczych, Kosowizna: Wydawnictwo Adriana Aviation.

Polska Klasyfikacja Zawodów.

Porczyńska A. (2006), Tendencja do podejmowania ryzyka a doświadczanie szczęścia, [w:] M. Goszczyńska, R. Studenski (red.), Psychologia zachowań ryzykownych, Warszawa: Wydawnictwo Akademickie „Żak”.

Reykowski J. (1996), Funkcjonowanie osobowości w warunkach stresu psychologicznego, Warszawa: Państwowe Wydawnictwo Naukowe.

Rozporządzenie Ministra Infrastruktury z dnia 24 czerwca 2009 r. zmieniające rozporządzenie w sprawie licencjonowania personelu latającego.

Siekańska M. (2005), Zadowolenie z pracy zawodowej osób wybitnie uzdolnionych, Lublin: Towarzystwo Naukowe KUL.

Strelau J. (1996), Temperament a stres: temperament jako czynnik moderujacy stresory, stan i skutki stresu oraz radzenie sobie ze stresem, [w:] I. Heszen-Niejodek, Z. Ratajczak (red.), Człowiek w sytuacji stresu, Katowice: Wydawnictwo Uniwersytetu Śląskiego.

Strelau J., Jaworowska A., Wrześniewski K., Szczepaniak P. (2005), Kwestionariusz Radzenia Sobie w Sytuacjach Stresowych CISS. Podręcznik, Warszawa: Pracownia Testów Psychologicznych PTP.

Studencki R. (red.) (2004), Zachowanie się w sytuacji ryzyka, Katowice: Wydawnictwo Uniwersytetu Śląskiego.

Szczepaniak P., Strelau J., Wrześniewski K. (1996), Diagnoza stylów radzenia sobie ze stresem za pomoca polskiej wersji kwestionariusza CISS Endlera i Parkera, „Przegląd Psychologiczny”, nr 39.

www.encyklopedia.pwn.pl (dostęp: 10.10.20116).

Zaleśkiewicz T. (2006), Ryzyko jako konieczność i ryzyko jako przyjemność. Teoria i jej empiryczna weryfikacja, [w:] M. Goszczyńska, R. Studencki (red.), Psychologia zachowań ryzykownych. Koncepcje, badania, praktyka, Warszawa: Wydawnictwo Akademickie „Żak”.

\section{SUMMARY}

The aim of the article is to analyze the results of studies of selected personality traits of pilots involved in test flights which may affect their safety at work. Given the characteristics of the profession, we selected three traits: risk appetite, coping with stress, and a sense of control in a work situation. The results indicate that test pilots definitely have a low risk appetite which means they are not taking the risk for pleasure or "thrill". Their leading style of coping with difficult situations is a style focused on completing a task. They are also individuals with higher than average intensity of feeling of internal control and self-esteem.

Keywords: risk; sense of control in a work situation; ways of coping with stress; test flight 